\title{
Fen Eğitiminde Disiplinlerarası Yönelimlerin STEM 'e Evrilmesi Sürecine Tarihsel Bir Bakış
}

Zeynep Akça ${ }^{1}$

\author{
Şenol Beşoluk ${ }^{2}$
}

Type/Tür:

/Derleme

Received/Geliş Tarihi: May 19/

19 Mayis 2020

Accepted/Kabul Tarihi:

December 12/ 12 Aralık 2020

Page numbers/Sayfa No: 556-578

Corresponding

Author/İletişimden Sorumlu

Yazar:

zeynep.akca1@ogr.sakarya.edu.tr

\section{$\checkmark$ iThenticate}

This paper was checked for plagiarism using iThenticate during the preview process and before publication. / Bu çalışma ön inceleme sürecinde ve yayımlanmadan önce iThenticate yazılımı ile taranmıştır.

Copyright (C) 2017 by

Cumhuriyet University, Faculty of Education. All rights reserved.

\section{Öz}

Doğal sistemlerin karmaşıklığı ve bu sistemlerinin açıklanmasının gereği, arka planda disiplinlerarası bir çalışmayı gerektirmektedir. Gerçek dünyanın fenomenlerini anlamanın en iyi yolunun disiplinlerarası bir bakış açısına sahip olmakla gerçekleştirilebileceği belirtilmekte; bu bağlamda pek çok ülkede eğitim programlarının içerikleri, disiplinlerarası biçimde ele alınmaya uygun hale getirilmektedir. Çalışmanın amacı, dünyada ve Türkiye'de disiplinlerarası fen eğitimi tarihini ve mevcut eğilimleri incelemek; disiplinlerarası öğrenmeye doğru meydana gelen paradigma kayması ile günümüzdeki durumunu ortaya koymak ve disiplinlerarası fen eğitimini destekleyen kavramsal çerçeveyi sunmaktır. Bu amaçla, çalışmada disiplinlerarası eğitim mantığının gelişimi, eğitimde disiplinlerarası çalışma metotları ve bu metotların süreç içindeki değişimleri ile bugünkü durumu ele alınmaktadır. Çalışma, literatür taramaya dayalı derleme çalışmasıdır. Fen eğitiminde disiplinlerarası yönelimlerin sınıflandırılması, değerlendirilmesi, süreçler arasında bağ kurulması ve yorumlanmasını içermektedir. Bu kapsamda fen programlarına yansıyan ve uygulama örnekleri bulunan disiplinlerarası yönelimler analiz edilmiştir. Bilimde disiplinlerarası çalışmalar ve disiplinlerarası çalışmaların dünyada ve Türkiye'de fen eğitimine yansıması tarihsel süreç içerisinde incelenmiş, disiplinlerarası program hazırlamanın kavramsal çerçevesi sunulmuştur. Ardından, Türkiye'de uygulanan fen öğretim programları ve programları değerlendiren çalışmalar incelenmiş, geçmişten günümüze öğretim programları içerisinde adı geçen disiplinlerarası yönelimler kısaca açıklanmıştır. Son bölümde, günümüzde ön plana çıkan STEM yönelimi ele alınarak değerlendirilmiş, kapsamı, başarısı, uygulamada diğer disiplinlerarası yönelimlerle benzerlik ve farklılıkları, uygulamaları etkileyen ülkeye özgü faktörlerin etkisi yönleriyle bazı belirsizliklerin olduğu sonucuna ulaşılmıştır.

Anahtar Kelimeler: Disiplinlerarası fen eğitimi, disiplinlerarası fen eğitiminin gelişimi, fen öğretim programları, disiplinlerarası yönelimler, STEM.

\section{Suggested APA Citation /Önerilen APA Atıf Biçimi:}

Akça, Z., \& Beşoluk, Ş. (2020). Fen eğitiminde disiplinlerarası yönelimlerin stem 'e evrilmesi sürecine tarihsel bir bakış. Cumhuriyet International Journal of Education, 10(2), 556-578. http://dx.doi.org/10.30703/cije.739869

\footnotetext{
${ }^{1}$ Bilim Uzmanı, Sakarya Üniversitesi, Eğitim Bilimleri Enstitüsü, Sakarya/Türkiye M.S., Sakarya University, Institute of Education Sciences, Sakarya/Turkey e-mail: zeynep.akca1@ogr.sakarya.edu.tr ORCID ID: orcid.org/0000-0001-8533-3186

2 Prof. Dr. , Sakarya Üniversitesi, Eğitim Fakültesi, Sakarya/Türkiye

Prof. Dr. , Sakarya University, Education Faculty, Sakarya/Turkey e-mail: sbesoluk@sakarya.edu.tr ORCID ID: orcid.org/0000-0002-9604-0749
} 


\title{
A Historical Perspective on the Evolution of Interdisciplinary Trends to STEM in Science Education
}

\begin{abstract}
The complexity of natural systems and the need to explain these systems require an interdisciplinary study in the background. It is stated that the best way to understand the phenomena of the real world can be achieved by having an interdisciplinary perspective; in this context, the content of educational programs in many countries makes them suitable for interdisciplinary consideration. The purpose of this study is to examine the history of interdisciplinary science education and current trends in the world and in Turkey; to present the current situation with the paradigm shift towards interdisciplinary learning and to present the conceptual framework supporting interdisciplinary science education. For this purpose, in this study, the development of interdisciplinary education trend, interdisciplinary study methods in education and the changes of these methods in the process and their current situation are discussed. Interdisciplinary studies in science and its reflection on science education examined in the historical process of the world and in Turkey, interdisciplinary conceptual framework of the preparation of the program were presented. Then, the science curriculum implemented in Turkey and studies of evaluating this programs were examined, the interdisciplinary trends that mentioned in this curriculum from past to present are briefly explained. In the last section, the STEM trend, which is prominent today, has been evaluated and it has been concluded that there are some uncertainties in terms of its scope, success, similarities and differences with other interdisciplinary trends in practice and the effects of country-specific factors affecting applications.
\end{abstract}

Keywords: Interdisciplinary science education, development of interdisciplinary science education, science education programs, interdisciplinary trends, STEM.

\section{Giris}

İnterdisipliner ya da disiplinlerarası yaklaşım, iki ya da daha fazla akademik disiplinin birleştirilmesi ya da bir arada ele alınmasıdır. Bilim ve teknolojideki hızlı gelişmeler, çeşitlenen problemler, toplumsal gelişime bağlı ihtiyaçlar ve uluslararası rekabet; hem bilimlerin birbirleriyle disiplinlerarası bir biçimde çalışmasını, hem de bu çalışmalarında teknolojiyi kullanmasını zorunlu hale getirmiştir. Araştırmageliştirme faaliyetleri arttıkça da disiplinlerarası çalışmaların önemi artmakta ve kapsamı genişlemektedir (Ulusoy, 2007). Çok disiplinli ve disiplinlerarası çalışmalar, birden fazla disiplinin bir arada çalışması bakımından benzerlik gösterseler de, çok disiplinli çalışmalarda farklı disiplinlerden gelen uzmanlar birbirinden bağımsız olarak sıralı veya eş zamanlı çalışabilirlerken, disiplinlerarası çalışmalarda ortak bir amaç için bir arada çalışırlar. Çok disiplinli çalışmalarda disiplinlerin sınırları göz ardı edilmez, farklı disiplinlerden gelen uzmanlar bir arada çalışırlar ve her biri farklı metotları kullanırlar, disiplinlerarası çalışmalarda ise disiplinler kendi sınırlarını aşıp iç içe geçer, senteze ulaşlır ve ortak metotlar kullanılır (Choi ve Pak, 2006). Eğitimde çok disiplinli çalışmalar yapılarak öğrencilerin bilgileri genişletilebilir; ancak disiplin perspektifinin analizine ya da disiplinlerarası senteze ulaşmada etkili olmaz. Disiplinlerarası çalışmalarda ise "bağlantı derinliği" söz konusudur, yani disiplinlere ait parçalar, daha kapsamlı ve anlamlı bir bütün olacak biçimde bir araya gelir (Klein, 2002). Konunun öğretimini disiplinlerarası bir yönelim ile ele almak, öğrencinin olayı neden- sonuç ilişkileri ile birlikte değerlendirmesine olanak sağlayacaktır. Çünkü doğası gereği insan, dış dünyayı bütünsel bir biçimde algılar. Problemlere çözüm 
bulma ve başkalarıyla iletişim kurma biçimleri belli disiplinlere ait bilgiler ile sınırlı değildir. Bilimsel düşünme becerilerinin kazanılmasında bir dereceye kadar belli bir disiplinin organize edilmiş halini sunmak gerekliyse de, uzun süreli bu şekilde bir sunum, yaşamdan kopuk bir birikim oluşturarak kişiyi öğrenmeye karşı isteksiz hale getirir (Yıldırım, 1996). Disiplinlerarası eğitim, tekil bir disiplin üzerinde uzmanlaşmanın yanı sıra, herhangi bir konunun analizinde, farklı disiplinlerden yararlanmayı ön plana çıkarır disiplinlere ait büyük parçaların analizine imkân sağlar ve kapsayıcıdır (Aktan, 2009). Bilgilerin katlanarak arttı̆̆1 günümüzde, eğitim politikalarının da çok boyutlu ve etkileşimli olması gerekliliği; dünyada ve dünyadaki değişimlerin etkisiyle Türkiye' de öğretim programlarının yenilenmesinin nedenini oluşturmaktadır. Öğretim programları incelendiğinde; üst düzey düşünme becerilerinin öğrenciye kazandırılmasının, çoğu dersin genel amaçları içerisinde yer aldığı görülmektedir (Yolcu, 2013; Milli Eğitim Bakanlığı [MEB], 2018). Bu çalışma literatür taramaya dayanan bir derleme çalışmasıdır. Derleme çalışmaları, yazarın araştırma yaklaşımına göre düzenlenen, belli bir konuda yapılan çalışmaların sınıflandırılması ya da değerlendirilmesini içerebilen, ilgili alanda eski ve yeni çalışmalar arasında bağ kurma, yorumlama veya konu ile ilgili düşünsel bir rota izleme amacı güdebilen araştırma türüdür (Herdman, 2006). Bu çalışmanın odak noktasını oluşturan fen eğitiminde disiplinlerarası yönelimlerin fen programlarındaki yansımalarının incelenmesinde; dünyadaki eğilimlerin Türkiye' de fen programlarını nasıl etkilediği üzerinde durulmuş; bu amaçla önce disiplinlerarası çalışmanın ne olduğu ele alınmıştır. Ardından Türk fen programları incelenerek, programda adı geçen disiplinlerarası yönelim türleri kısaca açıklanmış, son olarak da yönelimlerin süreç içinde STEM'e evrilmesi değerlendirilmiştir. Burada açıklanan disiplinlerarası uygulamaların kavramsal durumunu belirtmede literatürde farklı ifadeler bulunduğundan; bu çalışmada genel olarak tümü için “yönelim” ifadesi kullanılmıştır (Akınoğlu, Çoban ve Çubukçu, 2018). Literatür incelendiğinde; disiplinlerarası yönelimler ile ilgili uygulamaya dönük çalışmalarının sayıca çokluğuna rağmen, disiplinlerarası yönelimlerin bir arada ele alındığı, bu yönelimlerin ortaya çıkış, gelişme ve dönüşüm sürecini inceleyen çalışma sayısının az olduğu görülmüş, çalışmanın alana bu yönüyle katkı sağlayacağı düşünülmüştür.

\section{Bilimde Disiplinlerarasılık ve Fen Eğitimine Yansıması}

Rönesans dönemine kadar bilimler arasında net bir ayrım yoktu ve tüm bilimler doğa felsefesi olarak adlandırılmaktaydı. 18. yüzyılda bilimlerin gelişmesi ve uzmanlaşması sonucu yeni akademik disiplinlerin ortaya çıkmasıyla bilim; çeşitli kollara ayrılmış ve bu kollardan gelişmeye devam etmiştir (Yıldırım, 2018). Bilim, yüzyıllar boyunca hâkim disiplinlere dayalı olarak gelişse de, değişen bilim anlayışı disiplinlerin kapalı sınırlarının ötesine geçme ihtiyacını doğurmuştur. 1800`lü yıllarda Alman filozof Johann Friedrich Herbart tarafından tanımlanan "apperceptive mass" hareketinin takipçisi Tuiskon Ziller 1860`lı yıllarda, bölümlere ayrılmış izole konuların, yapılan çalışmalar etrafında birleştirilmesini önermiş ve disiplinlerin tekrar bir arada çalışmasını gündeme getirmiştir (Klein, 2002). 1930'lu yılların başında doğa bilimcileri ve felsefecileri "bilim hareketinin birliği" ile bilginin daha çeşitli ve çok yönlü perspektiflere sahip olduğunu ortaya koyarak, bilimlerin bölümlere ayrılması ile başlayan katı sınıflandırma anlayışına karşı çıkmışlardır. Bu hareket, 
artık bir bilginin tasviri için mutlak bir disiplinin hayati bir çerçeve olmadığını ortaya koymaktadır (Sun You, 2017). Akademik çalışmalar, sosyal reformlar ve teknolojideki gelişim disiplinlerarası çalışmalara ivme kazandırmış; 21. yüzyılda karmaşık meseleler tek bir disiplin ile açıklanamayınca, disiplinlerarası çalışmalar daha çok benimsenmiştir (Tripp ve Shortlidge, 2019). Örneğin Dünya Sağlık Örgütü'nün 11 Mart 2020 de pandemi olarak ilan ettiği Covid-19 salgını için; hastalığın yayılmasının önlenmesi ve tedavi edilmesi için tıp, farmakoloji, kimya, biyolojinin alt dalları, bilgi iletişim ve sağlık teknolojileri, biyoteknoloji gibi bilim dalları birlikte çalışırken; salgının etkilerinin psikolojik, sosyolojik, ekonomik, eğitimsel, istatistiksel sonuçlarının da ele alınması, çok geniş kapsamlı disiplinlerarası çalışmaları gerektirmektedir.

Eğitimde "bütünleştirilmiş" ya da "bütünleştirici” terimini ilk kez 1855' de Herbert Spencer, "Psikolojinin İlkeleri" adlı eserinde kullanmıştır. Bunu, 1898'de Alexis Berthard' in "bütünleştirilmiş eğitim teorisi" ve Johann Herbart' in "korelasyon teorisi" izlemiştir (Klein, 2006). Disiplinlerarası terimi ise ilk defa 20. yüzyılın ilk çeyreğinde ortaya çıkmış ve birden fazla disiplini içeren araştırmaların teşviki için bir kısaltma olarak kullanılmıştır. Aynı zamanda insanın bir bütün olarak ele alınıp geliştirilmesi gerektiği görüşünün yaygınlaşmasıyla birlikte eğitim yaşantılarının planlanmasında da etkili olmaya başlamıştır (Tripp ve Shortlidge, 2019). 1916'da bir sistemin ya da organizmanın tüm bölümlerinin ancak bütünle olan ilişkisi ile tanımlanabileceği şeklinde ortaya konulan Gestalt psikolojisi ve 1960'l1 y1llarda Piaget'in yapılandırmacı anlayışı, eğitimde bilginin bütünsel bir biçimde anlamlandırılmasına verilen önemi artırmıştır. Bruner'in yapılandırmacı bilişselcilik anlayışının öne sürdüğ ü “öğrenilen bilginin kişisel deneyim ve anlamlardan bağımsız olmadığı" fikri, öğrencilerin maksimum anlam sağlayabileceği, birbirine bağlı, özgün bir okul müfredatının ortaya çıkmasında etkisi olmuştur (Mathison ve Freeman, 1998). 1920'lerde disiplinlerarası terimi proje yaklaşımı ile birlikte müfredat bağlamında dile getirilmeye başlanmış, 1930'larda müfredattaki etkisini artırmış, 1940'larda probleme dayalı öğrenme boyutuyla programı etkilemiştir (Klein, 2006). 1958' de Bloom, sorgu odaklı bütünleşmiş bir müfredatı; 1959'da Tyler, müfredatta konular arasında yatay bağlantıların kurulması gerekliliğini savunmuşlardır (Akt. Sun You, 2017). 1960'larda disiplinlerarası çalışmalar, çok fazla disiplini içermeyen, herhangi bir müfredat için tanımlanmış şemsiye bir terim olarak kullanılmıştır (Newell, 2010).

Özelde, fen eğitimi açısından bakıldığında en önemli gelişmeler, 2. Dünya Savaşından sonra başlamış, Rusya'nın 1957 de Sputnik'i fırlatması üzerine ABD ve müttefiklerinin harekete geçmesiyle hız kazanmıştır. O dönemde NATO ve Varşova Paktı arasındaki denge ve rekabete dayalı iki kutuplu dünya düzeni nedeniyle Rusya'nın uzay yolculuğunda ön alması onun karşısında yer alan NATO ülkelerini ve özelliklede Amerika' yı daha fazla çaba gösterme doğrultusunda tahrik ve teşvik etmiştir. Oluşan teknolojik yarış, fen müfredatlarının geliştirilmesini zorunlu kılmış, bilim insanı ve mühendis yetiştirme konusunda okullara büyük sorumluluklar yüklemiştir (Sun You, 2017). Bu gelişmelerin etkisinde Türkiye'de de fen eğitimine yönelik çalışmalar hızlanmış, yurt dışında kullanılan bazı fen ve matematik kitapları Türkçeye çevrilmiştir (Turgut, 1989). 1980 yılından bu yana disiplinin kendisi, toplumsal ihtiyaçların gelişimi, teknolojideki yeni gelişmeler, bilimsel yenilikler, öğrenme kuramlarındaki değişmeler, değişen işgücü talepleri, ekonomik işleyiş ve bir 
dizi küresel baskı, ortaokul fen programlarındaki değişimi hızlandırmıştır. Fen eğitiminin toplumsal işlevi göz önünde bulundurulduğunda, yenilenen programlar ile bilgiler ve beceriler arasında uyum oluşturulmaya çalışılmıştır (Kalolo, 2016). 1988 de tüm öğrenciler için özgün ve bağlantılı bir fen müfredatı geliştirilebilmesi amacıyla derinlemesine çalışmalar başlamış, böylece bütünleşik/disiplinlerarası müfredatlar geliştirerek öğrencilerin günlük yaşam ihtiyaçlarının karşılanacağı biçimde ayrık bilgilerin birleştirilmesi ve sentezlenmesi sağlanmaya çalışılmıştır, böylece bilimin daha geniş kitleler tarafından anlaşılabilmesi amaçlanmıştır. 1996 da Amerika Birleşik Devletlerinde The National Science Education Standards (NSES) gereği, disiplinlerarası müfredat ve öğretimi hakkında okullarda öğretmenlerin uygun stratejileri kullanabilmeleri için programlar yeniden yapılandırılmıştır. Bu etkiler, Çin ve Kore gibi Asya ülkelerini de etkilemiş, bu ülkelerde de disiplinlerarası öğrenme ve öğretme için bir dizi program planlanmıştır. 2001'de Çin' de ilk ve ortaokullarda ülke çapında müfredat reformu tamamlanmış, dersler ve öğrencilerin gerçek yaşam deneyimleri arasında bağlantı kurulmaya çalışılmıştır. Kore hükumeti, benzer şekilde bilim, teknoloji, sanat, matematik, mühendislik alanlarının birleştirilmesi ile ilgili teşvikler sağlamıştır (Sun You, 2017).

Toplumsal işlevlerinin yanı sıra disiplinlerarası fen eğitimi hareketinin ortaya çıkmasındaki nedenlerden biri de, izole edilmiş disiplinlerin günlük deneyimleri açıklamadaki statik yapısıdır. Kişisel bilgi, deneyim ve bakış açılarının genel öğrenmenin gelişimine etkisi; araştırma ve sorgulama becerilerini müfredatın merkezine yerleştiren pedagojik yaklaşımlar bu statik yapı ile uyuşmamaktadır. Ayrıca, 21. yüzyılda temel başarı ihtiyacının karşılanmasında bir disiplinle ilgili derin bilgiye sahip olmanın yanında, bilgi alanları arasında bağlantı kurmanın rolü ve önemi anlaşılmıştır (Mathison ve Freeman, 1998).

\section{Disiplinlerarası Öğretim Programı Geliştirme Çalışmalarının Kavramsal Çerçevesi}

Disiplinlerarası yaklaşım, farklı disiplinlerin ortak öğrenmeler etrafında organize edilmesidir (Drake ve Burns, 2004).

Disiplinlerarası bir öğretim programı geliştirilirken, konuların ilgili olduğu uzmanlar mümkün olduğunca bir arada çalışmalıdır. Öncelikle kapsamı çok geniş veya çok dar olmayacak biçimde konu veya kavramlar belirlenmelidir; daha sonra belirlenen konu alt konulara ayrılarak, alt konuların ilgili olduğu disiplinler belirlenmeli ve konular ile disiplinlerin arasında sistematik bir yapı oluşturulmalıdır. Burada temel çıkış noktası, belli bir disiplin ya da disiplinler değil, başlangıçta belirlenmiş olan konudur. Daha sonra amaç, içerik, uygulama ve değerlendirme yöntemleri belirlenerek program oluşturulur. Oluşturulan program; öğretim içeriği bakımından zengin ve öğretim teknikleri bakımından çeşitliliğe uygun olmalıdır (Yıldırım, 1996). Fogarty (1991), tekil bir disiplin programından, bütünleştirilmiş bir eğitim programına doğru geçişte on model önerir: Bağlantılı modelde; ders içeriği, konular ve kavramlar arasında veya önceki yıllarda edinilen bilgilerle ilişkilendirilir. İç içe geçmiş modelde; öğretmen, konuların özel içerik bilgisinin yanında öğrencilerin düşünme ve sosyal becerilerinin de geliştirilmesini amaçlar. Sıralanmış modelde; birbirine benzeyen konular arka arkaya ele alınarak konuya özgü bilgilerin birlikte incelenmesi sağlanır. Paylaşmalı modelde; iki faklı disiplinin üst üste gelen kavramları odak noktasını oluşturur, bu odak noktası üzerinden ilerlemeye devam 
edilir. Örüntülü modelde; kullanışlı bir temaya ait bilgiler; faklı disiplinlerle örüntü haline getirilir, bu örüntüde disiplinler, fikirler ve kavramlar etrafında birleştirilir. Bağlı modelde; çoklu düşünme becerileri, sosyal beceriler ve teknolojiyi kullanma becerileri, çeşitli disiplinler yoluyla birbirine bağlanır. Bütünleştirilmiş modelde; kavramların ve konuların ortak noktalarının üst üste gelmesini sağlayacak bir ekip çalışması yapılır, konular yeniden organize edilir. Yoğunlaştırılmış modelde; bütünleştirme yoluyla edinilen bilgiler, öğrenen tarafından uzman bir bakış açısı ile detaylı olarak incelenir ve sonuçta öğrenen kendi sentezlerine ulaşır. Network modelinde; öğrenen, bütün öğrendiklerini bir uzman gözüyle inceler ve ilgili alandaki uzmanlarla bilgi paylaşımı sağlayan bir ağ oluşturur (Akt. Gürkan ve Gökçe, 1999). Disiplinlerarası öğretim değişik türden bilgilerin, kavramlar veya problemler etrafında etkili biçimde bütünleştirilmesidir. Eğitimin başarısı bir anlamda, bilgi ve becerilerin problemlerin çözümüne yönelik olarak kullanılabilmesine bağlıdır. (Yildirım, 1996).

\section{Türkiye' de Fen Öğretim Programlarındaki Disiplinlerarası Yönelimlere Bakış}

Türkiye' de, Cumhuriyet'in ilanından sonra fen programlarında 1950 'li yıllara kadar 1924, 1926, 1936 ve 1948 yıllarında değişiklik yapılmıştır (Yolcu, 2014). Bu dönemlerde, fen eğitiminde amaç, hedef ve içerik açısından sistemli bir programdan ziyade, ders ve konu listesi şeklinde bir program takip edilmiştir. 1940'l1 yılların başında özellikle köylerde yaşayan çocukların eğitime erişiminin kolaylaşması, köyde yaşayan insanların sağlık, tarım, el sanatları konularında beceri kazanması, köylerin sosyal ve kültürel bakımdan iyileştirilmesi ihtiyacına karşılık 1940 yılında yasal olarak kurulan köy enstitüleri, toplumsal kalkınmaya katkı sağlamıştır. Köy enstitülerinde halkın ihtiyaçlarına cevap verebilecek, üretimi ve verimliliği artırmaya yönelik derslere yer verilmiştir (Kartal, 2008). 1954-1955 yıllarında ilk kez öğrencilerin gelişimleri ve ihtiyaçları göz önünde bulundurularak bir taslak program oluşturulmasına rağmen, bu program genel eğitime yansıtılamamıştır. Bu dönemde ABD'de başlayan fen müfredatı geliştirme çabaları kısa sürede tüm Avrupa'ya yayılmış, 1960'ların başında da bu akım Türkiye' yi etkilemiş ve Türkiye' de müfredat geliştirme çalışmalarına hız kazandırmıştır (Ünal, Coştu ve Karataş, 2004). 1968 yılında Fen ve Tabiat Bilgileri dersi kapsamında bir öğretim programı geliştirilmiştir. $\mathrm{Bu}$ öğretim programının amacı; çocukların, yaşadıkları çevreyi tanıyan, çevreyle uyumlu, çevresini feni kullanarak bilen, ihtiyaçlarını karşılamada kendine yetebilen bireyler olarak yetişmesini sağlamak olup; bu yıllarda, deneyden çok gözlemin, uygulama ve araştırmadan ziyade bilmenin ön planda tutulduğu görülmektedir (Dindar ve Taneri, 2011). 1985 yılında fen bilgisini oluşturan branş öğretmenleri, ders kitaplarına dayalı müfredatlar oluşturmuşlar ve bu müfredatların amaç, hedef, içeriklerini yüzeysel bir şekilde ortaya koymuşlardır, bu dönemde halen ders kitapları, tebeşir ve tahtaya bağlı bir fen eğitiminin yapıldığı söylenebilir (Ünal, Coştu ve Karataş, 2004). 1992 yılında yapılan değişikliklerle, laboratuvar boyutu öne çıkarılmış, kavramların deneylerle, çeşitli süreçleri takip ederek, uygulayarak öğrenilmesi vurgulanmış ve deneysel süreçler ayrıntılı biçimde ele alınmıştır (Dindar ve Taneri, 2011). 2000 yılında geliştirilen ilköğretim fen bilimleri dersi müfredatı, 2004 yılında yenilenmiş, bu programla müfredata yeni bir bakış açısı kazandırılmış, dersin adı fen ve teknoloji olarak değiştirilmiştir. 2004 programı; getirdiği pek çok yeniliğin 
yanı sıra; fen, teknoloji, toplum, çevre boyutu içerisinde, günlük sorunların çözümünde fen ve teknolojinin kullanılmasını ön plana çıkarmıştır (Dindar ve Taneri, 2011; MEB, 2005). Bu programin vizyonunu, "bireysel farklilkları ne olursa olsun, tüm öğrencilerin, fen ve teknoloji okuryazarı bireyler olarak yetiştirilmesi" oluşturmaktadır (MEB, 2005). Öğrenmede ve değerlendirmede yapılandırmacı öğrenme teorisi esas alınmış; programdaki konular bilimsel süreç becerileri, tutum ve değerler ile ilişkilendirilmiştir. Öğrencilerin bir probleme çözüm bulmak için teknolojiyi kullanmaları ve basit teknolojik tasarımları yapmaları gerektiği belirtilmiştir (Çepni, 2016). Programdaki kazanım sayısının fazla olması, diğer ülkelerde uygulanan fen programlarına yaklaşmak istenmesi, programda vurgulanan yapısalcı öğrenme kuramının yanı sıra öğrenciyi aktif kılacak tüm kuram ve modellerin yeri geldiğinde uygulanmasının daha doğru olacağı gerekçeleriyle fen programı 2013 yılında tekrar revize edilmiş ve dersin adı fen bilimleri olarak değiştirilmiştir (Çepni, 2016). 2004 yılında yapılandırmacı öğrenme programa daha hâkimken, 2013 de öğrencinin kendi öğrenmesinden sorumlu olduğu, araştırma-sorgulamaya dayalı bir anlayış kabul edilmiştir. Yine bu programda öğrencinin bilgiye ulaşma isteğinin artırılması ve öğrenme-öğretme sürecinde informal öğrenme ortamlarından yararlanılması vurgulanmaktadır (Karatay, Timur ve Timur, 2013). Ayrıca, günlük yaşam sorunlarına karşı sorumluluk alma, sürdürülebilir kalkınma bilinci geliştirme, sorunların çözümünde bilimsel süreç becerilerini ve diğer yaşam becerilerini kullanma, sosyo-bilimsel konuları değerlendirirken bilimsel düşünebilme, bu programın amaçları arasındadır (Çepni, 2016). 2017'de ulusal ve uluslararası sınavlarda görülen başarı durumunun istenilen düzeyde olmaması, bilim ve teknolojideki hızlı gelişmeler, yeni öğrenme ve ölçme değerlendirme yaklaşımları, çağa uygun insan yetiştirmenin gerekliliği göz önünde bulundurularak fen programı yeniden düzenlenmiş; programa, değerler ve yetkinlikler, inovasyon ve girişimcilik becerileri eklenmiştir (MEB, 2017). Her sinif seviyesinin son ünitesi, fen ve mühendislik uygulamaları olarak belirlenmiş, 2018 yılında yapılan değişiklikle, fen ve mühendislik uygulamaları bir ünite olmaktan çıkarılmış ve öğrencilerin yıl içinde bu alanla ilgili yaptıkları çalışmaları, yılsonunda bilim şenliği aracılığıyla sunmalarının beklendiği ifadesine yer verilmiştir (MEB, 2018). Özellikle 2004 ve sonrasında geliştirilen programlarda, amaçlara uygun olarak; süreçte disiplinlerarası bağlantıların kurulması gerekli görülmektedir.

\section{Türk Fen Öğretim Programlarını Etkileyen Disiplinlerarası Yönelimler}

Disiplinlerarası çalışmalar yönünden dünyada ve buna paralel olarak Türkiye'de öğretim programlarında yer alan bazı yönelimler aşağıda kısaca açıklanmıştır:

Araştırma-sorgulamaya dayalı öğrenme. Araştırma-sorgulamaya dayalı öğrenme; Dewey, Gagne, Bruner, Piaget, Lawson gibi önemli kuramcılar tarafından ortaya atılmış olup, hiç kimsenin her şeyi öğrenemeyeceği ancak herkesin öğrenmeyi öğrenebileceği anlayışına dayanır; bilimin nasıl yapıldığını öğretilmesi önemlidir. Bir problemin tanımlanması, çözüme yönelik hipotezlerin ortaya konulması ve hipotezlerin test edilmesi süreçlerini içerir. Sorgulama sürecinde öğrenciler araştırma sürecinde elde ettikleri veriler arasındaki ilişkileri ortaya koyarlar, birbirleri ile fikirlerini paylaşırlar, veriler ve paylaşımlar ışı̆̆ında problemlerine cevap bulmaya çalışırlar (Ecevit, 2018). Sorgulama yoluyla öğrenmenin başlangıcının 1960'lara 
dayandığı iddia edilmesine rağmen, yönelimin Sokrates ve sokratik düşünme yönteminden doğduğunu ileri süren iddialar da mevcuttur. Zihinsel süreçleri geliştirmeyi amaçlayan, öğrenci merkezli bir yönelimdir; öğrencinin öğrenebilmesi için öncelikle merak etmesi gerektiği noktasından hareket eder, süreci öğrenci yönetir; öğretmenin görevi süreçte öğrencinin öğrenmesini kolaylaştırmak ve rehberlik etmektir (Karamustafaoğlu ve Havuz, 2016).

Proje tabanlı öğrenme. Proje tabanlı öğrenme ile ilgili ilk referans, 1918' de Kilpatrick'in kişisel gelişim ve bilgiyi temellendirmek için, anlamlı içeriklerin bir arada kullanması ile ilgili çalışmasıdır. Bu çalışmada, projelerde matematik, fen bilimleri ve sosyal bilimler arasında disiplinlerarası çalışmanın öğrencilere zengin bir kavramsal bilgi ve fikir sunduğu ileri sürülmektedir. Öğrencilerin ilgi alanlarına göre seçtikleri projeler, onları toplum ve iş hayatına hazırlar. Proje tabanlı öğrenme, öğrencileri gerçek sorunların araştırılmasına dâhil etmek için tasarlanan öğretmeye ve öğrenmeye dayalı kapsamlı bir yönelimdir; kapsamı geniş olduğundan da disiplinlerarasıdır (Blumenfeld vd. 1991; Kubiatko ve Vaculova, 2011). Tasar1 geliştirmeye, planlamaya, hayal etmeye ve kurgulamaya dayalı bir öğrenme ve üretme şeklidir. Buradaki taban kelimesi ile projenin bir hedef değil, bir altyapı unsuru olduğu ortaya konulmakta ve süreç yönelimli bir anlayışı benimsediği vurgulanmaktadır. Proje geliştirme aşamasında öğrencinin zihinsel yapısı sürekli olarak yeniden örgütlenmektedir. Bu anlayışla, öğrencilerin kendi öğrenmelerini organize edip yönlendirmeleri ve nihayetinde, öğrencinin yaratıcılı̆̆ının geliştirilmesi hedeflenmektedir. Proje tabanlı öğrenmenin genel amacı, bireyi analitik ve eleştirel düşünebilen, problem çözebilen, araştırma yapıp karar verebilen, sorumluluk alabilen ve işbirliği içinde çalışabilen bireyler olarak yetiştirmektir (Erdem, 2002). Proje geliştirme süreci; öğrencilere öğrenmeyi, bilgiyi günlük yaşama entegre etmeyi, ilgi ve becerilerini geliştirmeyi ve duruma bütünsel bir bakış açısıyla bakabilmeyi öğretmektedir (Korkmaz ve Kaptan, 2002).

Yapılandırmacılık. Yapılandırma kavramını ilk kez ortaya atarak eğitimde yapılandırmacılık akımının kuran Piaget'tir. Piaget'in bireyi öne çıaran bu yaklaşımın yanı sıra Vygotsky, bilginin yapılandırılmasında sosyo- kültürel çevrenin etkisine dikkat çekmiş ve sosyal yapılandırmacılık görüşünü ortaya atmıştır. Yapılandırmacılığa göre birey edilgen ve alıcı değil, etkin ve katılımcıdır, her bireyin olayları anlaması kendine özgü biçimde yapılandırılır ve diğer bireylerle örtüşmez, örtüşse de bu belirlenemez (Bayraktaroğlu, 2011). Yapılandırmacılık, temelde zihinsel bir süreç olup, bilginin olduğu gibi dışardan alınması yerine, öğrencinin kendi öğrenmesinden sorumlu olduğu ve bilgiyi kendisinin yapılandırdığı esasına dayanır. İlgili alana yönelik bilginin yanında yapılanma süreci, kültürel ve sosyal içeriklerden de etkilenir (Akpınar ve Ergin, 2005). Yapılandırmacılığa göre, zihinde bir araya getirilmiş bilgiler anlama olarak nitelendirilemez, bilgiyi algılamak ile bilgiyi yapılandırmak aynı anlama gelmez. Birey; çevresi ile etkileşimi sonucunda yeni edindiği bir bilgiyi kendi bilgileri doğrultusunda algilar (özümleme), yeni bilgi var olan bilgiyle birlikte zihinde yeniden organize edilir (düzenleme) ve ortaya çıkan yeni zihinsel yapı ile çevreye uyum sağlayarak dinamik bir dengeye ulaşır (dengeleme). Birey yalnızca alıcı konumundan çıkar, bilgiyi yorumlayabilen ve geliştirebilen bir konuma gelir. 
Argümantasyon tabanlı öğrenme. Araştırma ve sorgulamaya dayalı olarak, öğrencilerin soru sorma, çeşitli argümanlar oluşturma, argümanları mevcut bilgilerle karşılaştırma, karar verme, fikirlerini soru-iddia-delil bağlamında sunma becerilerini geliştirmeye yönelik olarak, bireysel, küçük veya büyük gruplar halinde çalışmalarını yürüttükleri bir süreçtir (Hasançebi ve Günel, 2013). Argümantasyon, ilk olarak Toulmin (1958) tarafından iddiaları verilere dayandırma ve uygun gerekçelerle ilişkilendirme süreci olarak tanımlanmıştır (Balcı ve Benzer, 2020). Argümantasyon tabanlı bilim öğrenme, bir bilim insanının bir kavramı ya da teoriyi açıklarken kullandığı sorgulama süreçleri içerir (Ulu ve Bayram, 2015). Sınıftaki uygulamaları, öğrencilerin soru-iddia-delil sürecinde kritik düşünme becerilerini geliştirir, farklı kavramlar arasındaki nedensellik ilişkilerini ortaya koymalarına yardımcı olur, bilimsel araştırma ile ilgili yeteneklerinin gelişmesine katkı sağlar (Demir ve İşleyen, 2019). Argümantasyon tabanlı fen eğitiminin amacı yalnızca fen kavramlarına hâkim olmak değil, bilimsel bir açıklama diline sahip olabilmektir (Kuhn, 2009). Fen okuryazarlığına katkı sağlama, kavramsal anlama, araştırma, eleştirel düşünme ve akıl yürütme becerilerini geliştirme, argümantasyon tabanlı öğrenmenin temel amaçları olarak kabul edilmektedir (Aydın ve Kaptan, 2014).

Probleme dayalı öğrenme. Probleme dayalı öğrenme; ilk olarak 1960'lı yıllarda bir problemi çözmeye yönelik konuları ve ilkeleri problem çözüm basamaklarına uygun olarak bir araya getirmenin; önce konuların anlatılıp, sonra problem çözülen ders anlatımlarına göre daha etkili olduğunun görülmesi ile başlamıştır. İlk kez Kanada'da McMaster Üniversitesinde tıp eğitiminde uygulanmıştır. Modelin temeli Dewey'e ve keşfederek öğrenme anlayışına dayalıdır, gerçek dünya problemlerini en etkili biçimde çözebilme, kritik düşünme, öğrenmeyi öğrenme, takım çalışması ve disiplinlerden gelen bilgilerin bir problem etrafında bütünleştirilmesini kapsar (Selçuk ve Şahin, 2008). Öğrencilerin, gerçek hayattaki bir problemi ele alıp, problemin çözümüne yönelik küçük gruplar halinde çalıştıkları, bilimsel süreç becerilerini kullandıkları, öğrencilere öğrenmeyi öğrenme becerisi kazandırmayı ve öğrenme kapasitesini artırmayı amaçlayan bir yönelimdir (Yaman ve Yalçın, 2005). Probleme dayalı öğrenmenin temel araçlarını, gerçek yaşama uygun problemlerin yer aldığı senaryolar oluşturur. Bu senaryolarla öğrenciler, karşılaştıkları probleme yönelik kendi içinde bütüncül, çoklu çözümler üretirler (K1lınç, 2007).

Çoklu zekâ. Çoklu zekâ teorisinin tarihi, Bernard Van Leer Vakfı tarafından yürütülen, insan potansiyelinin doğası ve geliştirilmesi ile ilgili bir proje çalışmasına dayanmaktadır. Daha sonra 1983'te Howard Gardner, insanların farklı bilişsel güçleri ve farklı öğrenme tarzlarına sahip olduğunu açıklayan bir kitap yazmıştır (Fyodorova, 2005). Bu yaklaşımda temel olarak zekâ alanları, görsel, işitsel, bedensel, matematiksel, sosyal, içsel, doğacı ve sözel olarak sekiz kategoriye ayrılmıştır. Genel olarak bireysel farklılıkların dikkate alındığı, bireyin sahip olduğu potansiyeli ortaya çıkarmaya ve geliştirmeye odaklanan bir yönelimdir. Her bireyin düşünüş tarzı aynı olmadığından, eğitim, bu yönüyle bireylerin farklı düşünme şekillerini dikkate alarak hizmet vermelidir (Akamca ve Hamurcu, 2005). Bireysel farklılıkların göz önünde bulundurulması, özellikle kavramların öğretilmesinde önem taşımaktadır. Çoklu zekâ yönelimi, birden fazla metodun kullanımını içerdiği için bağlantıların kurulması önemlidir (Köksal, 2006). Öğrencilerin farklı tipteki öğrenme stilleri ve yönelimlerinin belirlenmesi ve geliştirilmesi için eğitimde tüm disiplinlerden yararlanmak önemlidir. 
Çoklu zekâya dayalı bir ders tasarımında öğrenciler kendilerine sunulan çeşitlilik içinde güçlü ve zayıf yönlerini belirleyebilmekte ve birbiri ile paylaşabilmektedir (Talu, 1999).

STEM (FeTeMM). Fen, teknoloji, matematik ve mühendislik alanlarının birbiriyle bütünleşmiş biçimde ele alındığı, okul öncesinden yükseköğretime kadar tüm süreci kapsayan, bilginin uygulamaya ve nihayetinde ürüne dönüştürülmesini amaçlayan yönelimdir (Akgündüz, vd., 2015). Kökeni 1957 y1lına dayanmakta ise de STEM olarak adlandırılması 2001 yılında olmuştur (Yıldırım ve Türk, 2018). İlk adı ABD Ulusal Bilim Vakfı tarafından science, mathematics, engineering, technology kelimelerinin ilk harfleri ile SMET olarak kullanılmış, daha sonra, daha anlamlı olduğu düşüncesiyle STEM'e dönüştürülmüştür (Sanders, 2009). STEM kısaltmasını ilk olarak kullanan Dr. Judith Ramaley, STEM'i öğrencilerin gerçek problemleri çözebilmeleri ve çözüm fırsatları oluşturabilmeleri için kurdukları bağlantıların yer aldığ1 eğitsel bir sorgulama olarak tanımlamıştır (Karataş, 2018). STEM'in şekillenmesinde okullar için bazı mühendislik projelerinin geliştirilmesi de etkili olmuştur. Bu projeler zamanla Amerika'da yaygınlaştırılmıştır. 1986'da Richard Blais adında bir lise öğretmeninin başlattı̆̆ı öğrencilere temel mühendislik bilgilerinin verilmesiyle ilgili proje, 1997 'de birçok şirket ve hibe destekleriyle finanse edilip büyümeye devam etmiş ve K-12 öğrencilerini mühendislik kariyerini düşünmeye teşvik eden bir uygulamaya dönüşmüştür. Boston Bilim Müzesi tarafından 2004 yılında başlatılan ilköğretim öğrencileri ve öğretmenlerinin mühendislik becerilerini geliştirmek için hazırlanan projede bir müfredat dâhilinde eğitimler yapılmıştır (Mohr-Schroeder, Cavalcanti ve Blyman, 2015). Bunlara benzer projeler, farkl1 ülkelerdeki öğretim programlarında yapılan düzenlemeler ve uluslararası rekabetin bir sonucu olarak STEM'in temeli ABD tarafından atılmış olup, ülkedeki bilimsel ve teknolojik işgücü kapasitesi bakımından, iş dünyasının istediği nitelikte mühendis ve işçi bulamaması nedeniyle mevcut problemin çözümünün eğitimde aranması sonucunda geliştirilmiştir (Banks ve Barlex, 2014). STEM anlayışının gelişimi önce politik bir gündem ile başlamış, daha sonra üniversite programlarının güncellenmesi, okul dışı destek programlarının oluşturulması, eğitim kurumlarındaki faaliyetlerin idareciler, bilim insanları, vakıflar veya gönüllü kuruluşlar aracılığı ile yeniden düzenlemesiyle de pedagojik bir boyut kazanmıştır (Çepni, 2018). Eyaletlere mühendislik becerilerine programda yer vermeleri tavsiye edilmiş, devamında STEM ile ilgili yorumlar farklılaşmış ve disiplinlerarası olsun ya da olmasın STEM alanlarından herhangi birini ön plana çıkaran okullar, "burada STEM programı uygulanmaktadır" şeklinde okul tanımlamalarına gitmişlerdir. STEM'in benimsenmesi ve yaygınlaştırılmasında; teknolojinin gelişimi ve özellikle de uzay araştırmaları konusunda meydana gelen rekabet, öğrencilerin bilimsel düşünme performanslarının gözden geçirilmesi, uluslararası sınavlardaki göstergeler, ülkelerin fen ve matematik programlarında yaptıkları yenilikler, müfredatta teknolojinin ele alınması ile ilgili değerlendirmeler ve eğitim- sanayi iş birliğine fırsat sunan müfredat girişimi etkili olmuştur (Banks ve Barlex, 2014). ABD, bu alana yönelik olarak çalışanlara geniş bütçeler ayırmakta, STEM liseleri kurmakta; bilim merkezleri, bilim müzeleri, sivil toplum kuruluşları bu alanda büyük destekler sağlamaktadır (Akgündüz, vd., 2015). ABD, okul ve üniversiteler bünyesinde STEM merkezleri kurarak ve bu merkezlerde atölye çalışmaları yaparak, derslere ara disiplin olarak 
mühendisliği eklerken; Çin, lisede zorunlu dersler olan biyoloji, kimya ve matematiğe STEM'i entegre ederek ve öğretmen yetiştirme programlarına STEM konularını ekleyerek fen eğitimi sürecini yönetmektedir. Rusya öncelikli olarak yükseköğretimde kaliteyi artırmayı hedeflemekte, STEM uygulamaları ile matematik, mühendislik, tıp ve fen bilimleri programlarını üniversitelerin rehberliğinde geliştirmeye çalışmaktadır. Avrupa ülkeleri ise, 2002' den bu yana çeşitli öğretim kademelerindeki programlarda değişiklik yaparak, STEM'i programlarına entegre etmişlerdir. Türkiye' de ise STEM içeriğinin fen konularına uygulanması; TÜBITTAK projeleri ve yarışmaları ile teşvik edilmesi, bilim merkezlerinde düzenlenen aktiviteler, bazı üniversitelerin bünyesinde açılan STEM merkezleri, Avrupa Okul Ağ1 tarafından yürütülen Scientix çalışmaları yoluyla desteklenmektedir (MEB, 2016). STEM alanında yapılan çalışmaları; mühendislik uygulamalarının fen ve matematik bilgileri ile bütünleştirilmesi, mühendislik eğitiminin kalitesini artırmaya yönelik çalışmalar, ülkelerin geri kalmış bölgelerinde ve özellikle kız öğrencilerde STEM alanlarına yönelik ilgiyi artırma çalışmaları ve teknolojinin eğitimdeki rolü ve kodlama eğitimi çalışmaları olarak gruplayabiliriz (Çepni, 2018).

Türkiye' de STEM, öğrencilerin STEM alanlarını disiplinlerarası bir biçimde ele alıp, araştırma ve tasarım yapma, problem çözme, etkili iletişim kurma gibi özgün öğrenme ve üretme etkinliklerine dayanmaktadır. Böylece öğrencilerin, 21. yüzyıl bilgi ve becerilerine sahip bireyler olarak yetişmeleri ve bu alanlara yönelik çalışmalar yapmaları hedeflenmektedir (Baran, Canbazoğlu-Bilici ve Mesutoğlu, 2015). Morrison (2006), STEM'in problem çözme becerilerini geliştirdiğini, yaratıcılı̆̆ı, mantıksal düşünmeyi ve özgüveni artırdığını, teknolojinin doğasını açıklamayı ve anlamayı sağladığını ifade etmiştir. Bunlara ilave olarak eleştirel ve yaratıcı düşünmenin sağlanmasında, üst düzey düşünme becerilerinin geliştirilmesinde, bireylerin disiplinlerarası bir bakış açısı kazanmasında, kalıcı öğrenmenin gerçekleştirilmesinde STEM'in etkili olduğu söylenebilir (Micheal ve Okafor, 2016). Küresel bir perspektiften bakıldığında; STEM disiplinlerindeki bilgiler, ekonomi, politika ve kültürel değerlerle bağlantılıdır. Sağlık, enerji verimliliği, çevresel kalite, kaynak kullanımı, güvenlik gibi pek çok konuda daha iyi kişisel kararlar alabilecek vatandaşların yetiştirilmesini sağlar (Bybee, 2010a). STEM okur-yazarlığı, kültürel olarak tüm öğrenciler ve öğrenme stilleri için önemlidir. STEM anlayışında öne çıkan mühendislik ve tasarım boyutu ile kişinin problemin çözümüne yönelik farklı görüşler geliştirme, alternatif yollara karar verme, farklı çözüm kümeleri arasında değerlendirme yapmayı içeren bilişsel modelleme yollarının geliştirilmesine katkı sağlanması amaçlanmaktadır. Buradaki tasarım, sezgisel ve tümdengelimseldir, kaynakların nasıl kullanılacağını bilmekten öte, anlam ve bilgi inşa eden yorumlayıcı bir faaliyettir (Morrison, 2006). Çoğu eğitimci için STEM, yalnızca fen ve matematik eğitimi anlamına gelmektedir. Ancak, teknoloji ve mühendislik ürünlerinin günlük hayatı çokça etkilediği göz önünde bulundurulduğunda; gerçek bir STEM eğitimi, öğrencilerin teknolojiyi anlama ve geliştirme kapasitesini artırmalıdır. Mühendislik doğrudan problem çözüm ve yenilikle ilgilidir, mühendisliğin toplumdaki ekonomik rolü göz önünde bulundurulduğunda, öğrencilerin mühendislikle ilgili bilgi sahibi olması ve tasarım süreci ile ilgili beceri ve yeteneklerinin geliştirilmesi gerekir (Bybee, 2010b). STEM, öğretmenlere, öğrencilerin ilgi alanlarının fark edilmesi konusunda yardım eder, böylece öğrenciler daha başarılı kariyer edinebilirler (Tsupros, Kohler ve 
Hallinen, 2009). STEM eğitiminin ayrıca üstün yetenekli öğrencilerde yaratıcılık, eleştirel düşünme, işbirliği yapma, iletişim becerisi gibi 21.yüzyıl becerilerini geliştirdiği belirtilmiştir (Akgündüz ve Özçelik, 2018). STEM uygulamalarının derslerde öğrenmenin kalıcılığı, ilgi, motivasyon, tutum, problem çözme, eleştirel düşünme vb. becerileri geliştirme sağladığı ve uygulamaların gerekliliği hakkında pek çok çalışma bulunmaktadır (Aydın ve Baydere, 2019; Bybee, 2010a; Bybee, 2010b; Çevik, 2018; Çiftçi, Topçu ve Foulk, 2020; Çorlu, Capraro ve Capraro, 2014; Yıldırım ve Selvi, 2017).

\section{Tartışma, Sonuç ve Öneriler}

Fen eğitiminin disiplinlerarası amaçları Bybee (1993) tarafından; sosyal kalkınma ve toplumun isteklerine ulaşmak, bilimsel araştırma yöntemlerini kullanmak, öğrencinin kişisel gelişimini sağlamak ve kariyer bilincini geliştirmek, bilimsel fikirlerin kavramsal olarak da anlaşılabilmesini sağlamak, kanıta dayalı sonuçlar çıkarabilme yeteneği kazandırmak bileşenleri ile ele alınmıştır (Akt. Holbrook 2000).

Dünya disiplinlerarasıdır, disiplinlerarası eğitim bileşenleri, gerçek dünya olaylarına ayna tutarak disiplinlerin katı sınırlarını ortadan kaldırır (Styron, 2013). Müfredatlar gerçek yaşantılara yansıtıldıkça öğrenme, öğrenci için daha değerli hale gelir; bu nedenle düzenli konu paketlerinden çok yönlü müfredat yaklaşımına doğru geçilmelidir. $\mathrm{Bu}$ bağlamda öğretmen gelişimi için öğretmenlerin modern konular, problemler, değişen dinamikler, öğrenme aktiviteleri gibi konularda eğitim almaları, eğitim planlarının disiplinlerarası düzenlenmesi, sosyal konulardaki problemlerin derslere yansıtılması gerekir (Opara, 2014). Disiplinlerarası süreçlerin yapılanması; karşıt görüşlerin tanımlanması, görüşlere ortak bir zemin oluşturulması, fikirlerin birbirleriyle entegrasyonu, farklı anlayışları test etme ve sonucu ortaya koyma süreçleriyle açıklanabilir. Öğgrenilen bilgiler çeşitli perspektiflerden bakılarak anlamlı hale getirildiğinde, öğrenen kişinin potansiyelini artırabilir (Newell, 2010). Özellikle toplumu ilgilendiren konularda öğrencilerin sorumlu birer vatandaş olabilmeleri için, disiplinlerarası eğitime ihtiyaç vardır. Böyle bir eğitim onlara bilim, teknoloji ve etiğin, toplumun ayrılmaz parçaları olduğu anlayışını kazandırır (Adams ve Baker, 1986). Biyoçeşitliliğin azalması, küresel iklim değişiklikleri gibi karmaşık ve kapsamlı konularda çok sayıda disiplinin bir araya getirilmesine yönelik ihtiyaç artmıştır (Tripp ve Shortlidge, 2019). Ancak deneme-yanılmaya dayalı sahte disiplinlerarası çalışmalar, disiplinlerarası anlayışa zarar vermektedir. Ne tek başına politik ve sosyal ihtiyaçlar, ne de eğitim uygulamalarının yönetim ve organize edilmesi gerekçesi; öğrenme süreçleri, disiplin yapıları ve öğrenme çıktıları açısından yeterli ve güvenilir sonuçlar ortaya çıkarmaz. Daha derin bir tarihsel bağlamda, tanım ve uygulama örüntülerinin anlaşılması gerekir (Klein, 2006).

Eğitimde disiplinlerarası araştırmalara yapılan yatırım, farklı disiplinlerin bir araya getirilmesiyle ilgili büyük talepler doğurmuştur. Ancak disiplinlerarasılığın anlamı konusunda henüz senkronize olunamadiğı, bu durumun da disiplinlerarasılığın ölçütünü ve değerlendirilmesini güçleştirdiği görülmektedir (Lederman ve Lederman, 2013). Özellikle STEM ile ortaya çıkan yöntem, strateji, düşünce akımı tartışmaları yönündeki belirsizlikler yöntem "tabanında" yöntemlerin, yaklaşım "tabanında" yaklaşımların ortaya çıkmasına neden olmaktadır. Türkiye' de her ne kadar STEM disiplinlerarası uygulamaların geldiği son nokta olarak görünse de, uygulamaların bir öğretim stratejisi mi, yaklaşımı mı, düşünce akımı mı olduğuna 
yönelik kavramsal düzeyde tartışmalar ve uygulama boyutunda belirsizlikler devam etmektedir (Batı, Çalışkan ve Yetişir, 2017). STEM ile ilgili başka bir belirsizlik de tam olarak hangi disiplinleri kapsadığı ile ilgilidir. STEM içinde ifade edilen alanlar, fizik, kimya, biyoloji, astronomi, bilgisayar ve bilgi iletişim bilimleri, yer bilimleri, malzeme bilimi, matematik, mühendislik ve bunlarla ilgili teknolojidir. Buradaki "S, sosyal bilimleri ve davranış bilimlerini içerecek biçimde vurgulandığında STEM daha kullanışlı ve kapsayıcı bir kısaltma olacaktır. Ayrıca STEM kapsamına sanat, edebiyat, müzik gibi disiplinlerin eklenip eklenmemesiyle ilgili tercihler bulunmakta ise de, bununla ilgili kabul edilmiş bir standart yoktur (Breckler, 2007). Literatür ile Türkiye MEB raporları arasındaki bazı farklılıklar da STEM'in anlaşılmasını güçleştirmektedir. MEB (2016) raporunda fen, matematik, teknoloji ve mühendislik alanındaki teorik bilgilerin uygulama ve ürüne dönüştürülmesi açısından STEM eğitiminin oldukça önemli olduğu vurgusu, alan yazında STEM'in felsefi ve pedagojik altyapısı ile tam olarak uyuşmamaktadır. MEB ifadesinde disiplinlerin ayrı ayrı öğrenilip, devamında STEM eğitimi yapılması gibi bir durum söz konusu iken, alanyazında bir problemin çözümünde farklı disiplinlerin bilgisinden yararlanma bakımından STEM eğitiminin süreç boyutu ön plandadır (Çepni, 2018).

Gerek dünyada, gerekse Türkiye'de STEM'in yanlış anlaşılması ile ilgili sorunlar da mevcuttur. Morrison (2006), STEM ile ilgili; öğrenciler için ek bilgisayarlar gerektireceği, uygulamaların yalnızca işgücü ile ilgili sorunları çözmek için yapıldığı, bilimsel yöntemi ve laboratuvar çalışmalarını göz ardı ettiği, fen ve matematik eğitiminden ayrı olarak teknoloji ve mühendisliğin ele alınacağı yönünde yanlış anlaşılmaların olduğunu belirtmiştir. Çepni (2018); STEM eğitiminin algılanmasındaki köklü yanlışlıkları, "maker" hareketinin merkeze oturtulması, okullarda reklama dönük deney ve görsellerin sunulması, hobi kurslarının STEM olarak algılanması, kodlama eğitiminin vazgeçilmez bir unsur olarak gösterilmesi, felsefesine aykırı olarak üretimden çok tüketimi teşvik etmesi, kısa süreli eğitimlerle bu konuda dağıtılan sertifikalar olarak sıralamıştır.

STEM ile ilgili başka bir sorun da etkililiğinin ve başarısının değerlendirilmesi ile ilgilidir. STEM eğitiminin amacı, öğrencilerin problem çözme, mühendislikle ilgili bilgi ve becerilerini artırma ve yaratıcılıklarını geliştirme olarak düşünüldüğünde; başarısını fen ve matematik alan bilgileriyle ölçmek çok doğru görünmemektedir. Guzey, Moore, Harwell ve Moreno (2016) çalışmalarında, STEM uygulamalarının matematik ve mühendisliğe ilişkin öğrenme ve davranışlara olumlu etki ettiği ile ilgili anlamlı bir sonuç elde etmemişlerdir. Ayrıca STEM eğitimi ile yürütülen faaliyetler için gereken süre, tek alan öğretiminin verilmesi için geçen süreden daha uzun olduğu için, süre bakımından farklı olan bu iki uygulamayı başarı açısından karşılaştırmak da sorun oluşturmaktadır. Karşılaştırma boyutundaki bir diğer sorun ise, uygulayıcı öğretmenlerin STEM'i farklı anlaması ve uygulaması ile ilgilidir; öğretmenlerin kendi deneyimleri ve tutumları uygulamalarını etkilemektedir (Frykholm ve Glasson, 2005). STEM'in başarısını değerlendirmedeki bir başka zorluk, STEM'e atfedilen becerilerin değerlendirilmesinin sınırlı olmasıdır. Bilimsel sorgulama, kod yazma ya da mühendislik ilkelerinin uygulanmasını değerlendirme, standart ölçme değerlendirme araçları ile yeterince ölçülememektedir (Timms, Moyle, Mitchell ve Weldon, 2018). Bu nedenle STEM eğitiminin başarısını yorumlamak için daha sistematik, kapsamlı çalışmalara gerek duyulmaktadır (Çepni, 2018). Thomasian (2011), ABD ‘de, STEM 
anlayışının benimsenmesinden sonraki ilk on yıllık süreçte, ülkenin STEM eğitiminden tam olarak fayda göremediğini belirtmiş; bunun nedenlerini nitelikli öğretmen eksikliği, ortaöğretim sonrası STEM çalışmalarındaki hazırlık eksikliği, öğrencileri fen ve matematik alanlarına karşı motive etmedeki başarısızlık ve ortaöğretim sonrası eğitimin STEM iş taleplerini karşılamak konusundaki başarısızlığ1 olarak sıralamıştır. Avustralya'da öğrenmeyi zenginleştirecek öğretmenlerin yetersizliği, STEM müfredatlarının parçalı ve dengesiz bir şekilde ele alınması nedeniyle öğrencilerin bu alanlara ilgisinin azalması; öğrenci katılımını ve performansını artırmada istenilen sonucu vermemiştir (Timms, vd., 2018). Bu açıdan bakıldığında, yeterli hazırlıklar yapılmadığında Türkiye' de de benzer bir durumun ortaya çıkma ihtimali söz konusudur. Ayrıca Türkiye'de bölgeler ve okullar arasındaki sosyoekonomik farklılıklar, sınav odaklı eğitim sistemi ve eğitici eğitiminin yeterli düzeyde olmaması, STEM in uygulanması konusundaki bazı endişeleri oluşturmaktadır (Altunel, 2018). STEM öğretmenlerinin yetiştirilmesi için, öğretmen destekli ve öğrenci odaklı pedagojik eğitim gereklidir. Bazı deneyimli öğretmenler; alışkın oldukları biçimde, bu gerekliliğin aksine eğitimi öğretmen merkezli ve öğrenci destekli ele almaya devam etmektedir. Bunun sonucu olarak, pek çok STEM eğitmeni, öğrencilerin STEM içeriğine uygun becerileri değerlendirmede yetersiz kalmaktadır (Erdoğan ve Bozeman, 2015). Türkiye' de öğretmenlerle yapılan görüşmelerde, STEM uygulamalarını zorlaştıran etkiler öğretmenler tarafından, öğretmenin kendini yeterli görmemesi, kalabalık sinıflarda uygulama zorluğu, diğer alan öğretmenleri ile işbirliği yapmada zorluk, fiziki yapının uygun olmaması, materyal eksikliği, zaman problemi, müfredatın uygun olmaması, öğretmen eğitimin yetersiz kalması, sınıf dış1 etkinliklerde çevresel ve idari sorunlar olarak sıralanmıştır (Özbilen, 2018; Yıldırım, 2018; Kurtuluş, Akçay ve Karahan, 2017). Bu nedenle de Türkiye' de kısa vadede STEM eğitiminin başarısını değerlendirmek güçtür. STEM eğitiminin nasıl gerçekleştirileceği ile ilgili uygulamaların; hem öğretmen yetiştirmede, hem de mevcut öğretmenler için çeşitli eğitimlerle desteklenmesi gerekir. STEM, mevcut toplumsal taleplerin gereği olarak, yeni öğretim metotları ve değerlendirme yöntemleriyle müfredata girmiştir. Buna rağmen, geleneksel disiplinlerin her biri, kendine özgü temel becerileri geleceğe taşımaktadır. Bu nedenle eğitimcilerin her şeyden önce kendi alanı ile ilgili derinlemesine bilgi sahibi olması gerekir. Kendi alanı ile ilgili yeterli bilgisi olmayan bir öğretmenin bilgiyi diğer disiplinlerle ilişkilendirmesi de zordur. STEM'in geleceği; hem geleneksel, hem de geleneksel olmayan değerlendirme yollarıyla değerlendirilmeli, hem bireysel hem de bütünsel olarak ele alınmalıdır (Ostler, 2012). Timms ve diğerleri (2018), STEM uygulamaları ile oluşabilecek çeşitli sorunların çözümü için iyi düşünülmüş, sistematik ve birleştirilmiş politikalar geliştirilmesi gereğini, daha iyi eğitim uygulamalarının yapılabilmesi için öğretmenlerin çalışmaları ile ilgili daha iyi veri toplanmasını, okul dışı aktiviteler ile STEM alanlarına olan ilginin artırılmasını önermişlerdir.

Genel olarak eğitim sarkacı disiplinlerarası yönelimler arasında sallanıyor olmasına rağmen pek çok fen bilimci halen disiplin odaklı çalışmaya devam etmektedir (Sun You, 2017). Bunun nedenleri, alanındaki akademik bilgiye yeterince hâkim olamama, disiplinlerarası çalışmanın önemini kavrayamama, disiplinlerarası çalışma yetkinliğine ulaşamama, yeterince işbirliği ortamının oluşması, ders yükü, sınav baskısı vb. olarak sıralanabilir. Ayrıca özünde benzer olmalarına rağmen, 
disiplinlerarası yönelimlerin küçük farklılıklarla isim değiştiriyor olması, bu nedenle aralarındaki farkların tam olarak anlaşılamaması ve fen programlarındaki beklentiler, disiplinlerarası çalışmaları ve boyutlarını etkilemektedir. Programlara bu çalışma yöntemleri adapte edilirken, ülkenin ihtiyaçları, sosyo-ekonomik durumu, yerel kaynaklar, disiplinlerarası çalışmaları destekleyecek paydaşlar, yapılacak yatırım, eğitim ortamlarının durumu gibi pek çok faktör göz önünde bulundurulmalıdır. Öğretmenlere öğretim programının beklentilerini gerçekleştirmede açık ve net bir yol haritası sunulması gerekir. Örneğin; 2018 programına yansıtılan yenilikçilik, fen, mühendislik ve girişimcilik uygulamalarının pratiğe nasıl uygulanabileceğine dair somut materyaller öğretmenlere sunulmalıdır (Deveci, 2018). Disiplinlerarası çalışmalar ile ilgili organizasyonun tamamlanmış, hedeflerin net, açık ve somut bir biçimde sunulduğu, tüm paydaşların disiplinlerarası çalışma yeterliliğine sahip olduğu bir ortamda, disiplinlerarası yönelimlerin sağladığı faydaya daha büyük oranda ulaşılabilir. 2018 programında, fen konularında matematiksel ifadeler ve bağlantılarla ilgili ciddi sinırlamalar olduğu görülmektedir. Bu durum; fen ve matematik arasında bağlantı kurulmasını, fen konularının matematiksel yorumunun yapılmasını engellemektedir. Bu bağlamda, fen ve matematik ortaklı̆̆1 artırılabilir. STEM'in ABD'deki gelişimini göz önünde bulundurduğumuzda sanayi desteğinin önemli bir rolü olduğu görülmektedir. Türkiye'de de sanayi kuruluşları STEM eğitimine destek olabilirler.

\section{Kaynakça}

Adams, D. and Baker, R. (1986). Science, technology, and human values: An Interdisciplinary approach to science education. Journal of College Science Teaching, 15(4), 254-258.

Akamca, G. ve Hamurcu, H. (2005). Çoklu zekâ kuramı tabanlı öğretimin öğrencilerin fen başarısı, tutumları ve hatırda tutma üzerindeki etkileri. Hacettepe Üniversitesi Ĕ̆itim Fakültesi Dergisi, 28, 178-187.

Akgündüz, D. ve Özçelik, A. (2018). Üstün/özel yetenekli öğrencilerle yapılan okul dışı STEM eğitiminin değerlendirilmesi. Trakya Üniversitesi Eğitim Fakültesi Dergisi 8(2), 334-351.

Akınoğlu, O., Çoban, A. ve Çubukçu, Z. (2018). Öğrenme öğretmede yeni yönelimler. B. Oral (Ed.), Öğrenme öğretme kuram ve yaklaşımları (s.495-648, 4.baskı). Ankara: Pegem Akademi Yayıncılık.

Akpınar, E. ve Ergin, Ö. (2005). Yapılandırmacı kuramda fen öğretmeninin rolü. İlköğretim-Online, 4(2), 55-64.

Aktan, C. (2009). Yükseköğretimde değişim: Global trendler ve yeni paradigmalar. Organizasyon ve Yönetim Bilimleri Dergisi, 1(2), 78-79.

Altunel, M. (2018). STEM eğitimi ve Türkiye: Firsatlar ve riskler. Siyaset, Ekonomi ve Toplum Araştırmaları Vakfı Perspektif Dergisi, 207, 1-6.

Akgündüz, D., Aydeniz, M., Çakmakçı, G., Çavaş, B., Çorlu, M.S., Öner, T. ve Özdemir, S., (2015). STEM eğitimi Türkiye raporu: Günün modası mı yoksa gereksinim mi? İstanbul Aydın Üniversitesi. Retrieved from http://fs.hacettepe.edu.tr/hstem/dosyalar/STEMRaporu.pdf. 
Aydın, E. ve Karslı Baydere, F. (2019). Yedinci sınıf öğrencilerinin STEM etkinlikleri hakkındaki görüşleri: Karışımların ayrıştırılması örneği. Ondokuz Mayıs Üniversitesi Eğitim Fakültesi Dergisi, 38(1), 35-52.

Aydın, Ö. ve Kaptan, F. (2014). Fen ve teknoloji öğretmen adaylarının eğitimde argümantasyonun biliş üstü ve mantıksal düşünme becerilerine etkisi ve argümantasyona ilişkin görüşler. Eğitim Bilimleri Araştırma Dergisi, 4(2), 163188. https:/ / doi.org/10.12973/jesr.2014.42.10

Balc1, E., ve Benzer, S. (2020). Lisansüstü öğrencilerin argümantasyon tabanlı temelli öğretim yaklaşımına yönelik görüşleri. Online Science Education Journal, 5(1), 920.

Banks, F. and Barlex, D. (2014). Teaching STEM in the secondary school. Helping teachers meet the challange. Published by Routledge. https:/ / doi.org/10.4324/9780203809921

Baran, E., Canbazoğlu-Bilici, S. ve Mesutoğlu, C. (2015). Fen, teknoloji, mühendislik matematik (FeTeMM) spotu geliştirme etkinliği. Araştırma Temelli Etkinlik Dergisi (ATED), 5(2), 60-69.

Batı, K., Çalışkan, İ., ve Yetişir, Ö. (2017). Fen eğitiminde bilgi işlemsel düşünme ve bütünleştirilmiş alanlar yaklaşımı (STEAM). Pamukkale Üniversitesi Ĕ̆itim Fakültesi Dergisi, 41, 91-103. https://doi.org/10.9779/PUJE800

Bayraktaroğlu, C. E. (2011). Eğitimde yapılandırmacılık yaklaşımı ve eleştirel bir bakış (Yayımlanmamış Yüksek Lisans Tezi). Maltepe Üniversitesi, Sosyal Bilimler Enstitüsü, İstanbul.

Blumenfeld, P.C., Soloway, E. Marx, R.W., Krajcik, J.S., Guzdial, M. and Palincsar, A. (1991). Motivating project-based learning: Sustaining the doing, supporting the learning. Educational Psychologist, 26, 369-398.

Breckler, S.J. (2007). ' $S$ ' is for science. Retreived from https://www.apa.org/monitor/sep07/sd.

Bybee, R.W. (2010a). Advancing STEM Education: A 2020 vision. Technology and Engineering Teacher; 30-35.

Bybee, R.W. (2010b).What is STEM education? Science 329 (5995). DOI: 10.1126/science.1194998. Retreived from https:/ / science.sciencemag.org/content/329/5995/996.

Choi, B. and Pak, A. (2006). Multidisciplinarity, interdisciplinarty and transciplinarity in health research, services, education and policy: 1 . Definitions, objectives and evidence of effectiveness. Clinical and Investigative Medicine, 29 (6), 351.

Çepni, S. (2016). (ed.) Kuramdan Uygulamaya Fen ve Teknoloji Öğretimi. Ankara: Pegem Akademi Yayınları.

Çepni, S.(2018). (ed.). Kuramdan uygulamaya STEM eğitimi. Ankara: Pegem Akademi Yayınlar1. https:/ / doi.org/10.14527/9786052410561

Çevik, M. (2018). Impacts of the project based (PBL) science, technology, engineering and mathematics (STEM) education on academic achievement and career interests of vocational high school students. Pegem Ĕ̆itim ve Öğretim Dergisi, 8(2), 281-306. https://doi.org/10.14527/ pegegog.2018.012 
Çiftçi, A., Topçu, M. and Foulk, J. (2020). Pre-service early childhood teachers' views on STEM education and their STEM Teaching practices. Research in Science and Technological Education. DOI: 10.1080/02635143.2020.1784125.

Çorlu, M.S., Capraro, R.M. and Capraro, M.M. (2014). Introducing STEM education: Implications for educating our teachers for the age of innovation. Eğitim ve Bilim,39 (171), 74-85.

Demir, B. ve İşleyen, T. (2019). Argümantasyon tabanlı bilim öğrenme yaklaşımının öğrencilerin matematik başarılarına etkisi. Yüzüncü Yıl Üniversitesi Ĕ̆itim Fakültesi Dergisi, 16(1), 1084-1109. https:/ / doi.org/10.23891/efdyyu.2019.154

Deveci, İ.(2018). Türkiye'de 2013 ve 2018 yılı fen bilimleri dersi öğretim programlarının temel ögeler açısından karşılaştırılması. Mersin Üniversitesi Ĕ̆itim Fakültesi Dergisi, 14(2), 799-825. https:/ / doi.org/10.17860/mersinefd.342260

Dindar, H. ve Taneri, A. (2011). MEB 'in 1968, 1992, 2000 ve 2004 yıllarında geliştirdiği fen programlarının amaç, kavram ve etkinlik yönünden karşılaştırılması. Kastamonu Ĕ̈̆itim Dergisi, 19(2), 363-378.

Drake, S. M. and Burns, R. C. (2004). Meeting standards through integrated curriculum. Association for Supervisionand Curriculum Development.

Ecevit, T. (2018). Argümantasyon destekli araştırma-sorgulamaya dayalı öğretim uygulamalarının fen öğretmen eğitimindeki etkililiği. (Doktora tezi, Hacettepe Üniversitesi, Ankara). Erişim adresi: http:/ / www.openaccess.hacettepe.edu.tr:8080/xmlui/handle/11655/5278.

Erdem, M. (2002). Proje tabanlı öğrenme. Hacettepe Üniversitesi Ĕ̆itim Fakültesi Dergisi, 22, 172-179.

Erdoğan, N. and Bozeman, T.D. (2015). Models of Project-based learning for the 21.st century. A. Şahin (Ed.), A Practice-based Model of STEM Teaching, STEM Students on the Stage (SOS). Sense Publishers. https:// doi.org/10.1007/97894-6300-019-2_3

Fyodorova, A. (2005). Multiple Intelligence Theory in Improving the Quality of Virtual Education (Master's thesis, University of Joensuu, Joensuu). Erişim adresi: http://cs.joensuu.fi/pub/Theses/2005_MSc_Fyodorova_Anna.pdf.

Frykholm, J. and Glasson, G. (2005). Connecting science and mathematics insruction: Pedagogical context knowledge for teachers. School Science and Mathematics, 105(3), 127. https:/ / doi.org/10.1111/j.1949-8594.2005.tb18047.x

Guzey, S., Moore, T., Harwell, M. and Moreno, M. (2016). STEM integration in middle school life science student learning and attitudes. Journal of Science Education and Technology, 25:550. https:/ / doi.org/10.1007/s10956-016-9612-x

Gürkan, T. ve Gökçe, E. (1999). Eğitim programlarını bütünleştirmenin on yolu. (Educational Leadership, Robin Fogarty' den çeviri). Ankara Üniversitesi Ĕ̆itim Bilimleri Fakültesi Dergisi, 32 (1-2), 29- 39. https://doi.org/10.1501/Egifak_0000000136

Hasançebi, F. ve Günel, M. (2013). Argümantasyon tabanlı bilim öğrenme yaklaşımının dezavantajlı öğrencilerin fen bilgisi başarılarına etkisi. İlköğretim Online, 12(4), 1056-1073. 
Herdman, E. (2006). Derleme makale yazımında konferans ve bildiri sunumu hazırlamada pratik bilgiler (çeviri: Zeynep Dörtbudak). Hemşirelikte Eğitim ve Araştırma Dergisi, 3(1), 2-4.

Holbrook, J. (2000). Interdisciplinary education in science. G. Stochel, I. Maciejowska (Eds.). Interdisciplinary education challenge of 21.st. century guidebook (pp. 9-14). Poland: Fall Publising.

Kalolo, J.F. (2016). Global changes in science education and their implications for Secondary school science teaching and learning developing countries. Europan Journal of Education Studies, 1(3), 99-113.

Karamustafaoğlu, S. ve Havuz, A. (2016). Araştırma sorgulamaya dayalı öğrenme ve etkililiği. International Journal of Assessment Tools in Education, 3(1), 40-54.

Karataş, F. (2018). Eğitimde geleneksel anlayışa yeni bir s(i)tem. S. Çepni (Ed.), Kuramdan uygulamaya STEM eğitimi (s.55). Ankara: Pegem Akademi Yayınları. https:/ / doi.org/10.14527/9786052410561.02

Karatay, R., Timur, S. ve Timur, B. (2013). 2005 ve 2013 yılı fen dersi öğretim programlarının karşılaştırılması. Adıyaman Üniversitesi Sosyal Bilimler Enstitüsü Dergisi, 15, 233-264. https:/ / doi.org/10.14520/adyusbd.709

Kartal, S. (2008). Toplum kalkınmasında farklı bir eğitim kurumu: Köy Enstitüleri. Mersin Üniversitesi Ĕ̈itim Fakültesi Dergisi, 4(1), 23-36.

Korkmaz, H. ve Kaptan, F. (2002). Fen Eğitiminde proje tabanlı öğrenme yaklaşımının ilköğretim öğrencilerinin akademik başarı, akademik benlik kavramı ve çalışma sürelerine etkisi. Hacettepe Üniversitesi Ĕ̆itim Fakültesi Dergisi, 22, 91-97.

Kılınç, A. (2007). Probleme dayalı öğrenme. Kastamonu Eğitim Dergisi, 15(2), 561-578.

Klein, J. T. (2002). Interdisciplinary education in K-12 and college: A foundation for K-16 dialogue. New York, NY: College Board Publications.

Klein, J.T. (2006). A platform for shared discourse of interdisciplinary education. Journal of Social Science Education, 5(4), 10-18.

Köksal, M. (2006). Kavram öğretimi ve çoklu zekâ teorisi. Kastamonu Eğitim Dergisi, 14(2), 473-480.

Kubiatko, M. and Vaculova, I. (2011). Project-based learning: Charasteristic and experiences with application in the science subjects. Energy Education Science and Technology Part B: Social and Educational Studies, 3(1): 65-74.

Kuhn, D. (2009). Teaching and learning science as argument. Science Education, 94(5), 810-824. https:// doi.org/10.1002/ sce.20395

Kurtuluş, A., Akçay, A. ve Karahan, E.(2017). Ortaokul matematik derslerinde STEM uygulamalarına yönelik öğretmen görüşleri. Ĕgitim ve Öğretim Araştırmaları Dergisi, 6(4), 354-360.

Lederman, N. and Lederman, J.(2013). Is it STEM or "S\&M" that we truly love? Journal of Science Teacher Education, 24, 1237-1240. https:/ / doi.org/10.1007/s10972-013-9370-z

Mathison, S. and Freeman, M. (1998). The logic of interdisciplinary studies. Paper presented at the annual meeting of the American Educational Research Association, Chicago.

Milli Eğitim Bakanlığı [MEB] (2005). İlköğretim (4 ve 5. Sinıflar) fen ve teknoloji dersi ögretim programı. Ankara: Milli Eğitim Bakanlığı. 
Milli Eğitim Bakanlı̆̆1 [MEB] (2016). STEM eğitimi raporu. MEB Yenilik ve Eğitim Teknolojileri Genel Müdürlüğü. https://yegitek.meb.gov.tr/STEM_Egitimi_Raporu.pdf

Milli Eğitim Bakanlı̆̆1 [MEB] (2017). Fen bilimleri dersi öğretim programı. Ankara: Milli Eğitim Bakanlığ1

Milli Eğitim Bakanlı̆̆1 [MEB] (2018). Fen bilimleri dersi öğretim programı. Ankara: Milli Eğitim Bakanlığ1

Micheal, C. and Okafor, K. (2016). STEM Education: A Tool for Sustainable National Capacity Building in a Digital Economy. 1. International Conference. FUTO-CCE.

Mohr-Schroder, M., Cavalcanti, M. and Blyman, K. (2015). STEM education. Understanding the changing landcape. A. Şahin (Ed.). A Practice-Based Model of STEM Teaching. STEM Students on the Stage, 3-14. Sense Publishers.

Morrison, J.S. (2006). Attributes of STEM education, the students, the academy, the classroom. TIES STEM Education Monograph Series.

Newell, W.H. (2010). Complex world integrative learning and interdisciplinary studies, Liberal Education, 6-11.

Opara, J. (2014). Innovative method of teaching science through interdisciplinary approach, Scholarly Research Journal for Interdisciplinary Studies, 2(12), 15501558.

Ostler, E. (2012). 21st century STEM education: A tactical model for long-range success International Journal of Applied Science and Technology, 2(1), 28-33.

Özbilen, A. (2018). STEM eğitimine yönelik öğretmen görüşleri ve farkındalıkları. Bilimsel Eğitim Araştırmaları Dergisi, 2(1), 1-21.

Sanders, M. (2009). STEM, STEM education, STEMmania. The Technology Teacher. 68(4), 21-26.

Selçuk, G. ve Şahin, M. (2008). Probleme dayalı öğrenme ve öğretmen eğitimi. Dokuz Eylül Üniversitesi, Buca Eğitim Fakültesi Dergisi, 24, 12-19.

Sun You, H. (2017). Why teach science with an interdisciplinary approach: History, trends, and conceptual frameworks, Journal of Education and Learning, 6(4), 6677. https://doi.org/10.5539/jel.v6n4p66

Styron, R. A. (2013). Interdisciplinary education: A reflections of real world. Systemics, Cynerbetics and Enformatics, 11(9). 47-52.

Talu, N. (1999). Çoklu zekâ kuramı ve eğitime yansımaları. Hacettepe Üniversitesi Eğitim Fakültesi Dergisi, 15, 164-172.

Timms, M., Moyle, K., Mitchell, P. and Weldon, P. (2018). Challenges in STEM learning in Australian schools. Literature and policy review. Australian Council for Educational Research, ISBN 978-1-74286-499-0.

Thomasian, J.,(2011). Building a science, technology, engineering, math education agenda: An update of state actions. Retrieved from https:/ / files.eric.ed.gov/fulltext/ED532528.pdf.

Tripp, B. and Shortlidge, E. (2019). A framework to guide undergraduate education in interdisciplinary science. CBE Life Sciences Education, 18(2), 1-12. https:/ / doi.org/10.1187/cbe.18-11-0226

Tsupros, N., Kohler, R. and Hallinen, J. (2009). STEM Education: A project to identify the missing components. Department for STEM Education and Leonard Gelfand Center for Service Learning and Outreach at Carnegie Mellon University, 1-35. 
Turgut, F.(1989, Mayıs). Türkiye' de fen ve matematik programlarını yenileme çalışmaları. Fen ve Yabancı Dil Öğretmenlerinin Yetiştirilmesi Sempozyumu, Hacettepe Üniversitesi.

Ulu, C. ve Bayram, H. (2015). Argümantasyon tabanlı bilim öğrenme yaklaşımına dayalı laboratuvar etkinliklerinin 7. Sınıf öğrencilerinin kavram öğrenmelerine etkisi: $\quad$ Yaşamımızdaki elektrik ünitesi. Pamukkale Üniversitesi Ĕ̆itim Fakültesi Dergisi, 37(1), 61-75.

Ulusoy, G. (2007). Disiplinlerarası araştırma ve eğitim. C. Aktan (Ed.) Değişim Çă̆ında Yüksek Öğretim: Global Trendler- Paradigmal Yönelimler (s.389-398). İzmir: Yaşar Üniversitesi Yayınları.

Ünal, S., Coştu, B. ve Karataş, F. (2004). Türkiye' de fen bilimleri eğitimi alanında program geliştirme çabalarına genel bir bakış. Gazi Eğitim Fakültesi Dergisi, 24(2), 183-202.

Yaman, S. ve Yalçın, N. (2005). Fen bilgisi öğretiminde probleme dayalı öğrenme yaklaşımının yaratıcı düşünme becerilerine etkisi. İlköğretim-Online, 4(1), 4252. https:// dergipark.org.tr/tr/pub/ilkonline/issue/8609/107241.

Yıldırım, A. (1996). Disiplinlerarası öğretim kavramı ve programlar açısından doğurduğu sonuçlar. Hacettepe Üniversitesi Eğitim Fakültesi Dergisi, 12, 89-94.

Yıldırım, B. (2018). STEM uygulamalarına yönelik öğretmen görüşlerinin incelenmesi. Eğitim Kuram ve Uygulama Araştırmaları Dergisi, 4(1), 42-53.

Yildırım, B. ve Selvi, M. (2017). An experimental research on effects of STEM applications and mastery learning. Eğitimde Kuram ve Uygulama. 13(2), 183210. https:/ / doi.org/10.17244/eku.310143

Yıldırım, B. ve Türk, C. (2018). Sınıf öğretmeni adaylarının STEM eğitimine yönelik görüşleri: Uygulamalı bir çalışma. Trakya Üniversitesi Eğitim Fakültesi Dergisi, 8(2), 195-213. https://doi.org/10.24315/trkefd.310112

Y1ldırım, C. (2018). Bilim Tarihi (22. Basım). İstanbul: Remzi Kitabevi.

Yolcu, F. (2013). Illköğretim düzeyinde performans görevleri ve proje uygulamaları sürecinde disiplinlerarası yaklaşımın etkililiği üzerine bir çalışma. (Doktora tezi, Hacettepe Üniversitesi, Ankara). Erişim adresi:

http://www.openaccess.hacettepe.edu.tr:8080/xmlui/handle/11655/1871

Yolcu, O. (2014). Cumhuriyetten günümüze ilköğretim birinci kademe hayat bilgisi ve fen ve teknoloji öğretim programlarının çevre eğitimi açısından incelenmesi. (Yüksek lisans tezi, Adnan Menderes Üniversitesi, Aydın). Erişim adresi: http://adudspace.adu.edu.tr:8080/xmlui/handle/11607/407

\section{Summary}

\section{Introduction}

The interdisciplinary approach is to combine or address two or more academic disciplines. Rapid developments in science and technology, diversified problems, needs related to social development, and international competition; has made it compulsory for the sciences to work with each other in an interdisciplinary manner and to use technology in these studies. As research and development activities increase, the importance of interdisciplinary studies increases and their scope expands 
(Ulusoy, 2007). The term interdisciplinary in education first appeared in the first quarter of the 20th century and was used as a bureaucratic shortcut for the promotion of research involving multiple disciplines. At the same time, with the widespread view that people should be addressed and developed as a whole, it became effective in planning educational experiences (Tripp and Shortlidge, 2019). Since 1980, the discipline itself, development of social needs, new developments in technology, scientific innovations, changes in learning theories, changing labour demands, economic functioning and a series of global pressures have accelerated changing of secondary school science programs. Considering the social function of science education, it has been tried to establish coherence between renewed programs and knowledge and skills (Kalolo, 2016). Accordingly, when developing an interdisciplinary curriculum, experts with whom the topics are relevant should work together. The topics discussed should be divided into sub-topics, disciplines related to sub-topics should be determined, and a systematic structure should be established between topics and disciplines (Yildırım, 1996). This study examines how interdisciplinary studies affected education, how to follow interdisciplinary curriculum preparation, how interdisciplinary studies in education have changed from past to present and finally evaluations about STEM.

\section{Method}

This study is based on a review of the literature. In the study of the reflections of interdisciplinary trends in science education, which is the focus of this study; of science program in Turkey, it has been examined how affected by global trends, for this purpose, what is the interdisciplinary study is discussed first. Then, how an interdisciplinary science program can be developed is emphasized. Subsequently, trends to science education, called interdisciplinary approaches, were researched using Turkish and English keywords. Specified selection criteria in the literature, interdisciplinary approaches in the literature to be reflected in the Turkish science program and the availability of the applied samples in Turkey. Then, by examining the Turkish science programs, the types of interdisciplinary approaches mentioned in these programs were briefly explained, and finally the evolution of the trends to STEM was evaluated in the process. In this context, the development of STEM in the historical process and its implementation in other countries are discussed.

\section{Results}

The interdisciplinary approaches considered in this context are project-based learning, argumentation-based learning, problem-based learning, constructivism, multiple intelligence and STEM. As a result of the literature review, it has been concluded that there are some uncertainties regarding the implementation of STEM, which is emphasized in the program. One of the reasons for these uncertainties is that there is no consensus on the meaning and scope of interdisciplinarity. Therefore, it is understood that practices differ from institution to institution and STEM's similarities and differences are not distinguished when compared to other interdisciplinary trends. Another problem with STEM is related to the evaluation of its effectiveness and success. Difficulty in measuring and evaluating STEM skills such as creativity, 
scientific inquiry, problem-solving engineering skills, shows that more systematic and comprehensive studies are needed.

\section{Discussion}

According to the literature, in the USA, during the first decade after the adoption of the STEM approach, the country did not fully benefit from STEM education; the reasons for this are the lack of qualified teachers, the lack of preparation in postsecondary STEM studies, the failure to motivate students in the fields of science and mathematics and the failure to meet the STEM labour demands (Thomasian, 2011). Students' interest in these areas has decreased due to the insufficiency of teachers who will enrich learning in Australia and the STEM curricula being handle in a fragmented and unbalanced way; did not give the desired result in increasing student participation and performance (Timms at al., 2018). Comparing the success of STEM with other approaches becomes difficult due to the involvement of different variables such as training of STEM teachers and the time allocated for STEM practices. When examined from this point of view, if not done sufficient preparations, also subject likely to occur in a similar situation in Turkey. Socioeconomic differences between regions and schools in Turkey, exam-oriented education system, lack of adequate training of trainer, constitute some concerns about the implementation of STEM (Altunel, 2018). In the event that the organization related to interdisciplinary studies is completed, the objectives are presented in a clear and concrete way, and all stakeholders have the interdisciplinary competence, the benefits of interdisciplinary approaches will be achieved to a greater extent. In addition, appropriate environments should be provided for teachers to prepare for the profession and then deepen their knowledge of their own fields, connections to be established between the courses should be strengthened, should be increased cooperation between experts in different fields and ensured wider industry support. However, it has been concluded that it is necessary to eliminate the uncertainties mentioned in the pursuance.

\section{Pedagogical Implications}

Although the benefits of addressing science education with interdisciplinary approaches are expressed, false interdisciplinary studies with wrong methods can harm the interdisciplinary approach. Neither political and social needs alone, nor the need to organize educational practices; it does not yield sufficient and reliable results in terms of learning processes, discipline structures and learning outcomes. In a deeper historical context, it is necessary to understand the definition and application patterns of interdisciplinary work in education, and increase the level of competence of the stakeholders who will take part in this field.

\section{Araştırmanın Etik Taahhüt Metni}

Yapılan bu çalışmada bilimsel, etik ve alıntı kurallarına uyulduğu; toplanan veriler üzerinde herhangi bir tahrifatın yapılmadığı, karşılaşılacak tüm etik ihlallerde "Cumhuriyet Uluslararası Eğitim Dergisi ve Editörünün” hiçbir sorumluluğunun olmadığı, tüm sorumluluğun Sorumlu Yazara ait olduğu ve bu çalışmanın herhangi başka bir akademik yayın ortamına değerlendirme için gönderilmemiş olduğu sorumlu yazar tarafından taahhüt edilmiştir. 


\section{Authors' Biodata / Yazar Bilgileri}

Zeynep AKÇA Sakarya Üniversitesi Eğitim Bilimleri Enstitüsü, Fen Bilgisi Eğitimi Bölümünde doktora yapmaktadır.

Zeynep Akça She is doing her doctorate studies in Sakarya University Institute of Educational Sciences, Science Education Department.

Şenol BEŞOLUK Sakarya Üniversitesi, Eğitim Fakültesi, Matematik ve Fen Bilimleri Eğitimi Bölümünde profesör doktor olarak görev yapmaktadır.

Şenol Beşoluk He works as a professor doctor in Sakarya University, Faculty of Education, Department of Mathematics and Science Education. 